\title{
Studies on antifertility effects of gossypol acetic acid in domestic cocks
}

\author{
J. Mohan, J. N. Panda, U. S. Singh* and R. P. Moudgal \\ Division of Physiology \& Reproduction, Central Avian Research Institute, Izatnagar (UP) 243122 , \\ India
}

\begin{abstract}
Summary. Daily oral administration of gossypol acetic acid $(40 \mathrm{mg} / \mathrm{kg}$ body weight daily) resulted in a gradual decrease in the semen volume and sperm concentration. Fertility dropped to zero at the end of the treatment period. Activities of acrosin, hyaluronidase and angiotensin converting enzyme were also drastically decreased by the end of the treatment period. A loss of appetite, loss of body weight and morphological abnormalities in spermatozoa were noticed in the treated cocks. At 4 weeks after cessation of the treatment, full recovery of the above measures was recorded. Healthy chicks were hatched and were observed for several months.
\end{abstract}

Keywords: gossypol acetic acid; antifertility; cock spermatozoa; hyaluronidase; acrosin; angiotensin converting enzyme

\section{Introduction}

Gossypol, a polyphenolic colouring agent present in the seed of the cotton plant (Gossypium hirsutum, Family Malvaceae), has contraceptive properties. An antifertility effect of gossypol has been demonstrated in male rats, rabbits, mice, hamsters, guinea-pigs, dogs, pigs, monkeys and men (National Coordinating Groups on Male Infertility Agents, 1978; Xue et al., 1980; Prasad \& Diczfalusy, 1982). It has been suggested that the toxic effects of gossypol involve uncoupling oxidative phosphorylation, inhibiting the enzymes involved in the respiration and energy metabolism (Abou-Donia \& Dieckert, 1974). Uncouplers allow electron transport to proceed but prevent the phosphorylation of ADP to ATP (Lehninger, 1975). Gossypol and gossypol-acetic acid have also been shown to exert direct effects upon production and maturation of spermatozoa, including inhibition of cell motility (Aitken et al., 1983).

Acrosin (EC 3.4.21.10) plays a role in the hydrolysis of the inner vitelline of the hen's egg, a membrane possibly homologous to the mammalian zona pellucida (Ho \& Meizel, 1975). Hyaluronidase (EC 3.2.1.36) is widespread in the semen of mammals (Stambaugh \& Buckley, 1970). It has been suggested that hyaluronidase plays a role in passage of spermatozoa through the zona pellucida by modifying the structure of this membrane to make it more susceptible to the action of acrosin (Hartree, 1971; Stambaugh et al., 1969). The presence of angiotensin converting enzyme (EC 3.4.15.1) in chicken spermatozoa was demonstrated by Mohan et al. (1987). Some preliminary studies on the role of this enzyme in mammalian sperm capacitation were reported by Singh et al. (1985) and Foresta et al. (1987). Although much information is available on the inhibition of sperm motility, enzymic activities and fertility after gossypol acetic acid treatment in a number of mammalian species (Xue et al., 1980; Lin et al., 1981; Kalla et al., 1986), there is no literature on the effects of gossypol in birds. The present studies were therefore conducted to obtain information on the antifertility effectiveness of gossypol acetic acid in male chicken.

*Present address: Division of Biochemistry, I.V.R.I., Izatnagar (UP) 243 122, India. 


\section{Materials and Methods}

Healthy adult White Cornish chicken weighing $3.5-4.0 \mathrm{~kg}$ body weight were housed in individual cages under constant husbandry conditions. They were kept on a normal breeders ration and water ad libitum at a temperature of $25-30^{\circ} \mathrm{C}$ with $14 \mathrm{~h} \mathrm{light/day} \mathrm{(lights} \mathrm{on} 05: 30 \mathrm{~h}$ ) and were divided into two groups. In Group I, 5 chickens served as controls and received vehicle ( $0 \cdot 5 \%$ carboxymethyl cellulose in $0 \cdot 9 \%(\mathrm{w} / \mathrm{v}) \mathrm{NaCl})$ by oral intubation for 18 days. The 5 chickens in Group II received gossypol acetic acid in $0.5 \%$ carboxymethyl cellulose by the same route for the same time at a rate of $40 \mathrm{mg} / \mathrm{kg}$ body weight $/$ day. The doses were given daily until progressively diminishing semen volumes ceased and watery droppings occurred. After the treatments were discontinued, a resting period of 7 days followed during which no semen collections were made. In the treatment and recovery periods, semen volume was measured by a pipette and sperm concentrations were determined with a Neubauer haemocytometer (Lake, 1960). The percentages of abnormal spermatozoa were counted after preparing smears and staining them with eosin and nigrosin according to the methods described by Lake \& Stewart (1978). Samples of semen were collected at different time intervals and centrifuged at $750 \mathrm{~g}$ for $10 \mathrm{~min}$ to separate sperm cells which were washed three times with saline $(0.9 \%(\mathrm{w} / \mathrm{v}) \mathrm{NaCl})$. Enzymes from spermatozoa were extracted in Triton X-100 $(0 \cdot 1 \% \mathrm{v} / \mathrm{v})$.

Hyaluronidase activity was assayed by the method of Alfred (1974). Hyaluronic acid (1.25 mg/ml buffer) in $50 \mathrm{~mm}-$ acetate buffer, $\mathrm{pH} 4.0$, containing $0.15 \mathrm{M}-\mathrm{NaCl}$ was incubated at $37^{\circ} \mathrm{C}$ with enzyme for 30 min. The reaction was terminated by the addition of $0.2 \mathrm{ml} 0.8 \mathrm{M}$-potassium tetraborate, $\mathrm{pH} 9 \cdot 1$, followed by heating in a boiling water bath for $3 \mathrm{~min}$. The solution was cooled to room temperature and $3 \mathrm{ml}$ dimethylaminobenzaldehyde reagent were added. The mixture was incubated at $37^{\circ} \mathrm{C}$ for $20 \mathrm{~min}$ and read at $585 \mathrm{~nm}$. Enzyme activity was expressed as nmol $N$ acetylglucosamine liberated per min per $\mathrm{mg}$ protein from hyaluronic acid at $37^{\circ} \mathrm{C}$. Acrosin was assayed by the method of Martinek et al. (1964) using $\alpha$ - $N$-benzoyl-DL-arginine- $\beta$-naphthyl-amide $\mathrm{HCl}$ (BANA) as the substrate. The assay mixture contained BANA $(10 \mathrm{mg} / 0.2 \mathrm{ml}$ of dimethylsulphoxide diluted to $10 \mathrm{ml}$ by $0.05 \mathrm{M}$-phosphate buffer, pH 7.5), phosphate buffer and enzyme. The incubation was carried out at $37^{\circ} \mathrm{C}$ for $30 \mathrm{~min}$. The reaction was stopped by the addition of $0.5 \mathrm{ml} 4 \mathrm{~N}-\mathrm{HCl}$. The amount of 2-naphthylamine formed by the hydrolysis of BANA was determined by adding $0.5 \mathrm{ml}$ freshly prepared sodium nitrite $(0.2 \% \mathrm{w} / \mathrm{v})$. The contents were thoroughly mixed and $1 \mathrm{ml}$ ammonium sulphamate $(0.5 \% \mathrm{w} / \mathrm{v})$ was added. After $3 \mathrm{~min}, 2 \mathrm{ml} \mathrm{N}-1$-naphthylethylenediamine dehydrochloride $(0.05 \% \mathrm{w} / \mathrm{v})$ in ethanol were added. Intensity of violet blue colour was read at $540 \mathrm{~nm}$, after $40 \mathrm{~min}$. Units of activity were expressed as $\mu \mathrm{mol}$ BANA hydrolysed per min per $\mathrm{mg}$ protein at $37^{\circ} \mathrm{C}$. The assay of angiotensin converting enzyme was performed by the spectrophotometric method of Cushman \& Cheung (1971). The total assay mixture contained $0.1 \mathrm{M}-$ borate-sodium carbonate buffer, $\mathrm{pH} 8.3 ; 0.8 \mathrm{M}-\mathrm{NaCl} ; 3.5 \mathrm{~mm}$-hippurylhistidylleucine (Hip-His-Leu) and various amounts of enzyme. The assay mixture was incubated at $37^{\circ} \mathrm{C}$ for $30 \mathrm{~min}$ and the reaction was stopped by adding $0.5 \mathrm{ml} 1 \mathrm{~N}-\mathrm{HCl}$. Hippuric acid was extracted with $3 \mathrm{ml}$ ethyl acetate by vortex mixing for $30 \mathrm{sec}$. Then $2 \mathrm{ml}$ of extract were evaporated and dried and $3 \mathrm{ml}$ distilled water were added. The concentration of hippuric acid was determined by measuring the absorbance at $228 \mathrm{~nm}$ against a zero time blank prepared by adding $0.5 \mathrm{ml} 1 \mathrm{~N}-\mathrm{HCl}$ to the assay mixture before reaction. One unit of the enzyme activity was defined as the amount of the enzyme catalysing the release of $1 \mu \mathrm{mol}$ hippuric acid from Hip-His-Leu per min per mg protein at $37^{\circ} \mathrm{C}$. Protein was estimated by the technique of Lowry et al. (1951).

To estimate the fertilizing ability of semen samples during and after drug administration, 72 White Leghorn hens were divided into 4 equal groups. After 1 week of drug treatment 18 hens in Groups A and B were inseminated with semen $\left(60 \times 10^{6}\right.$ spermatozoa) collected from cocks in Groups I and I1, respectively. Semen was diluted 1:4 with Beltsville Poultry Semen Extender within 20 min of collection (Sexton, 1977). After the end of experiment, artificial insemination (AI) was not performed for the treated birds, because they were producing only transparent fluid (without spermatozoa). To determine the recovery of fertility, hens in Groups $\mathrm{C}$ and $\mathrm{D}$ were inseminated with the semen collected from the cocks in Groups I and II, respectively, 4 weeks after cessation of treatment. The fertility of semen samples was assessed by incubating the eggs laid by the hens $2-10$ days after the intravaginal insemination of diluted semen. The eggs were examined after 4 days of incubation to determine fertilization.

After the recovery period, eggs were collected from hens inseminated with the semen of treated birds to determine any residual deleterious effect of gossypol acetic acid on the spermatozoa. The eggs were incubated, hatched and the chicks were observed for several months.

\section{Results}

Throughout the treatment period, a gradual reduction in semen volume (Table 1), sperm concentration (Table 1), and activities of acrosin (Fig. la), hyaluronidase (Fig. 1b) and angiotensin converting enzyme (Fig. 1c) were observed in Group II birds. Fertility dropped to zero (Table 2) at the end of treatment period. On microscopical examination, increased incidences of morphological abnormalities in the tail region (defective mid-piece and coiled tail) from a mean percentage of abnormalities of $3.75 \pm 0.21$ to $23.76 \pm 2.77$ in spermatozoa after the first week of treatment was noticed. However, the other types of abnormalities remained almost the same as those of the 
control. This was also observed for the spermatozoa collected 2 weeks after cessation of treatment. Based on measurements of food consumption, depression of appetite was observed. There was a significant $(P<0.001)$ reduction in body weight from a mean weight of $3.86 \pm 0.05 \mathrm{~kg}$ to $3.25 \pm 0.06 \mathrm{~kg}$ in 18 days but no significant change was observed in controls. Weakness of the legs was also observed in the treated birds.

Table 1. Effect of gossypol acetic acid on semen volume $(\mathrm{ml})$ and sperm concentration $\left(\times 10^{9} / \mathrm{ml}\right)$ of cocks

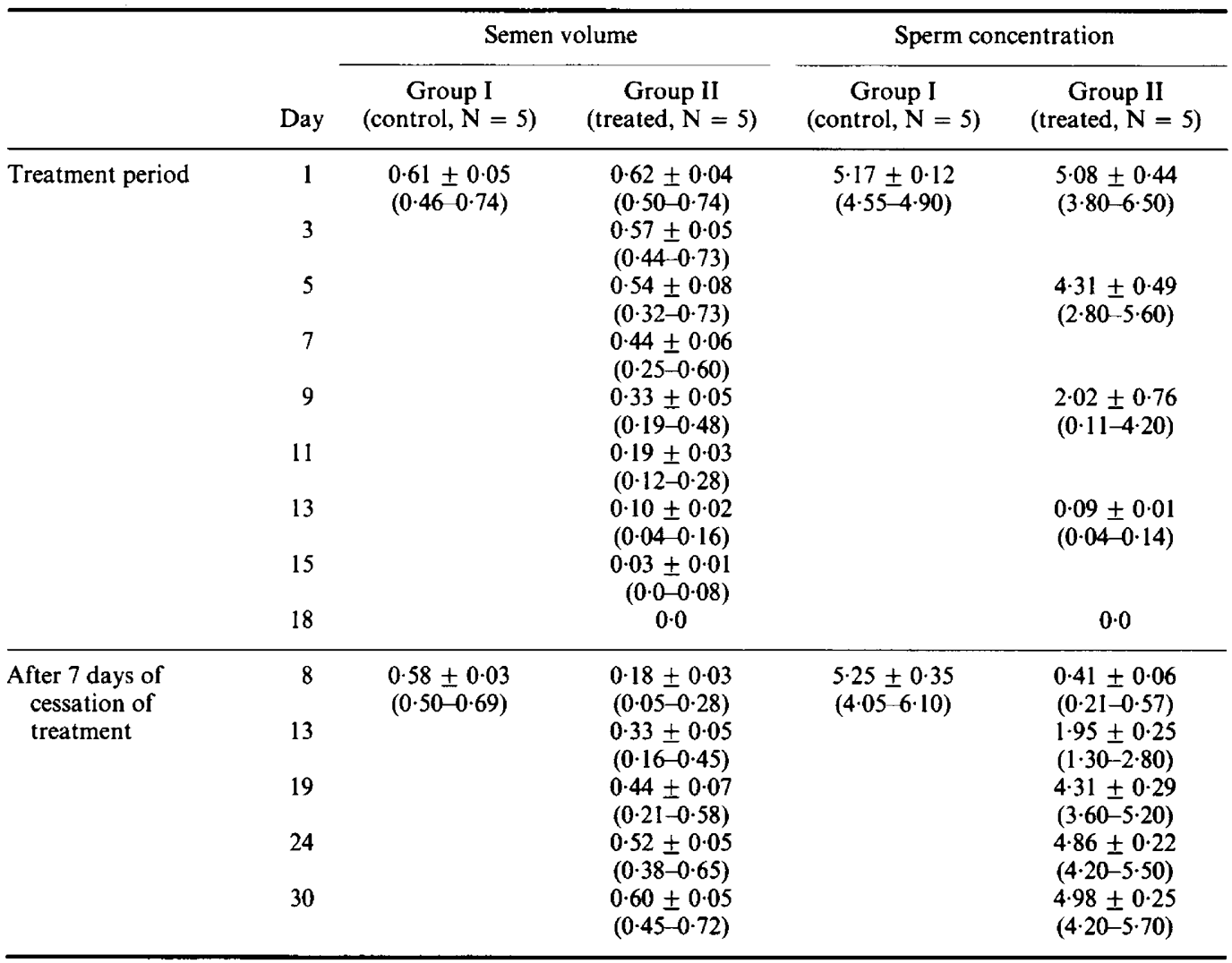

Values are mean \pm s.e.m. (range).

Table 2. Effect of gossypol acetic acid on the fertilizing ability of cock spermatozoa (\% fertile eggs laid during Days 2-10 after AI, hens/ group)

\begin{tabular}{lccc}
\hline & Day & $\begin{array}{c}\text { Group I } \\
\text { (control, N = 5) }\end{array}$ & $\begin{array}{c}\text { Group II } \\
\text { (treated, N = 5) }\end{array}$ \\
\hline Treatment period & 8 & 76.31 & 32.39 \\
$\begin{array}{l}\text { At 4 weeks after } \\
\text { cessation of treatment }\end{array}$ & 18 & 78.60 & 0 \\
\hline
\end{tabular}




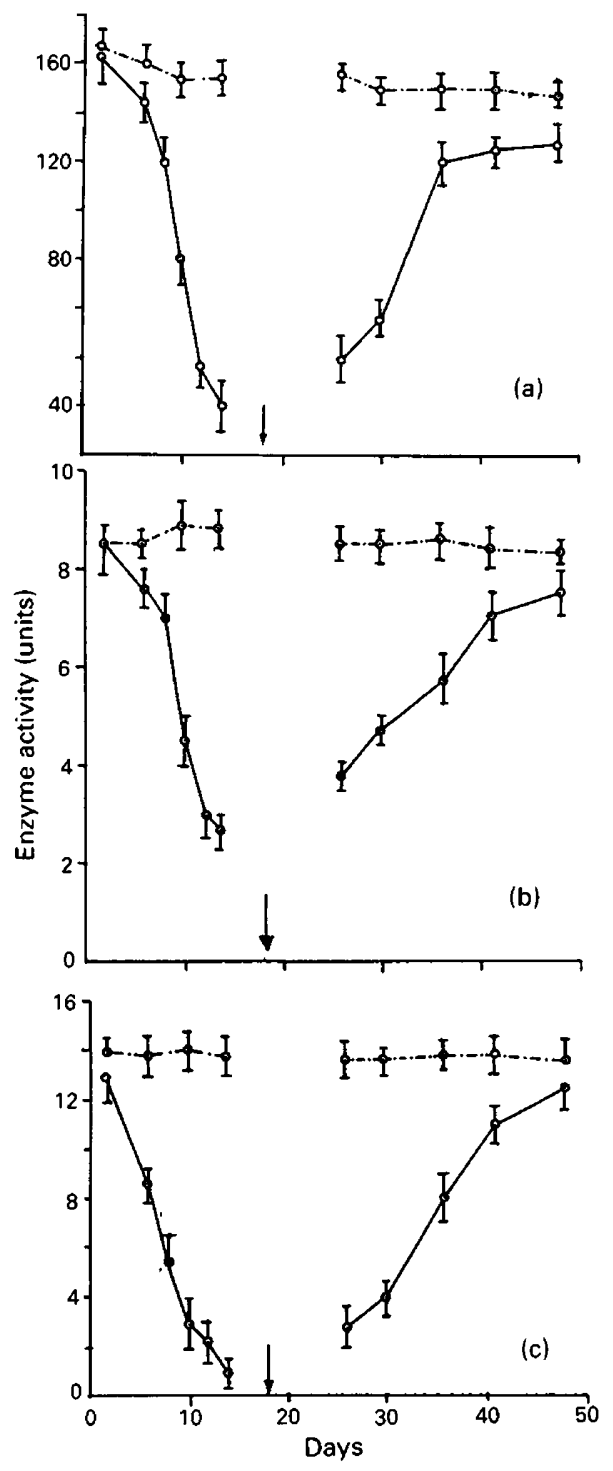

Fig. 1. Effect of gossypol acetic acid on activity (units, see text) of (a) acrosin, (b) hyaluronidase and (c) angiotensin converting enzyme of domestic cocks. Values are mean \pm s.e.m., $n=8$. Arrow indicates the discontinuation of the treatment followed by 7 days of a resting period during which no semen collections were made. $\mathrm{O}---\mathrm{O}$ control group; $\mathrm{O}-\mathrm{O}$ treated group.

At 4 weeks after cessation of treatment normal testicular functions were resumed as shown by the results. The chicks produced after hatching were all apparently healthy and no abnormalities were observed when they were examined for several months.

\section{Discussion}

The present results show that enzymic activities and fertility were significantly reduced in cocks by gossypol acetic acid treatment. In view of the known action of this compound in mammals, it is 
likely that the reduction in fertility observed in cocks was brought about by disruption of the production or release of testosterone secretion (Lin et al., 1981), breakdown of the blood-testis barrier (Pelletier \& Friend, 1980), and inhibition of cell motility (Aitken et al., 1983). Inhibition of such universal cell functions prevents spermatogenesis and sperm maturation. The drop in fertility noted in the present study might be due to the increased percentage of morphological abnormalities (in the tail region) in the treated group because a constant number of spermatozoa was inseminated in both groups. Haffer (1983) demonstrated abnormal spermatozoa due to ultrastructural defects, mainly in the mitochondrial sheath, in rats fed with gossypol. It has been reported that gossypol acetic acid inhibits the conversion of pepsinogen to pepsin (Tanksley et al., 1970). This may be responsible for the depression of appetite and, in turn, loss of body weight during the treatment period. Reduction in body weight (approximately 16\%) and other parameters partly may be due to the decrease in metabolizable energy values of food consumption since gossypol interferes in absorption of protein and carbohydrate constituents of food (Rojas \& Scott, 1969). Studies by Sharlin et al. (1981) on the effects of aflatoxin in male birds demonstrated that a reduction in food consumption alone attributed for over half the effects of this agent on body and testes weights, semen volume, sperm concentration and plasma testosterone. Furthermore, Wilson et al. (1979) indicated that a low protein diet, when consumed by mature roosters for 2 weeks, caused a $12 \%$ loss of body weight and $59 \%$ decrease in plasma testosterone. This may be true for gossypol acetic acid since this compound affects the production of testosterone secretion (Lin et al., 1981). Engster et al. (1978) concluded that reduced energy intake by cockerels tended to decrease secretion of pituitary gonadotrophins. In ejaculated spermatozoa the drug prevents the conversion of proacrosin into acrosin and, in turn, directly inhibits fertilizing ability of the spermatozoa (Tso \& Lee, 1982). A decreased pattern of the activity of acrosin (Fig. 1a) in our study may be due to the same reason. We have recorded $8.50 \pm 0.70 \mathrm{nmol}$ hyaluronidase $/ \mathrm{mg}$ protein $/ \mathrm{min}$ in Triton X-100treated cock spermatozoa, although these values were quite low in comparison to those of mammals (Stambaugh \& Buckley, 1970). However, little or no enzyme activity was reported by Saeki \& Morichi (1959). Dose-dependent inhibition of the acrosomal reaction was reported by Shi \& Friend (1983). Inhibition of the activity of acrosin and hyaluronidase (Fig. Ib) in our study indicated failure of the acrosomal reaction. Since this acrosomal reaction is a vital factor in fertilization, the deleterious effect on the acrosomal reaction must be an additional aspect of the antifertility action of gossypol acetic acid. Angiotensin-converting activity has been reported as being involved in the fertilization process (Singh et al., 1985; Foresta et al., 1987). The present results show that gossypol acetic acid causes a profound reduction in angiotensin converting activity (Fig. 1c) and oligospermia was also observed, and is in good agreement with our earlier observation (Mohan et al., 1987).

In the present study, after 4 weeks from the end of treatment full recovery and normal fertility were achieved. From this investigation it may be concluded that the effect of gossypol acetic acid on chicken spermatozoa is reversible.

We thank the Director of CARI and all other Scientists of the Division of Physiology \& Reproduction for their help in completing this work.

\section{References}

Abou-Donia, M.B. \& Dieckert, J.W. (1974) Gossypol: uncoupling of respiratory chain and oxidative phosphorylation. Life Sci. 14, 1955-1963.

Aitken, R.J., Liu, J., Best, F.S.N. \& Richardson, D.W. (1983) An analysis of the direct effects of gossypol on human spermatozoa. Int. J. Androl. 6, 157-161.

Alfred, L. (1974) Hyaluronidase. In Methods of Enzy- matic Analysis, 2nd edn, Vol. 2, pp. 944-948. Ed. H. U. Bergmeyer. Academic Press, London.

Cushman, D.W. \& Cheung, H.S. (1971) Spectrophotometric assay and properties of the angiotensin converting enzyme of rabbit lung. Biochem. Pharmacol. 20, 1637-1648.

Engster, H.M., Carew, L.B., Jr \& Cunningham, T.J. 
(1978) Effects of an essential fatty acid deficiency, pair feeding and level of dietary corn oil on the hypothalamic-pituitary-gonadal axis and other physiological parameters in the male chicken. $J$. Nutr. 108, 889-900.

Foresta, C., Indino, M., Mononi, F. \& Scandellari, C. (1987) Angiotensin converting enzyme content of human spermatozoa and its release during capacitation. Fert. Steril. 47, 1000-1003.

Haffer, A.P. (1983) Effects of gossypol on the seminiferous epithelium in the rat: a light and electron microscope study. Biol. Reprod. 28, 1007-1020.

Hartree, E.F. (1971) Lysosomes and fertilization. In Microbes and Life, pp. 271-303. Eds J. Monod \& E. Borek. Columbia University Press, New York.

Ho, J.J.L. \& Meizel, S. (1975) Hydrolysis of the hen egg vitelline membrane by cock sperm acrosin and other enzymes. J. exp. Zool. 194, 429-438.

Kalla, N.R., Gadru, N. \& Foo, T.W. (1986) Studies on the male antifertility agent gossypol acetic acid VII. Effect of motility stimulated factors on the revival of human spermatozoal motility after gossypol treatment in vitro. Andrologia 18, 393-397.

Lake, P.E. (1960) Studies on the dilution and storage of fowl semen, J. Reprod. Fert. 1, 30-35.

Lake, P.E. \& Stewart, J.M. (1978) Artificial insemination in poultry. Bull. 213, Her Majesty's Stationery Office, London, England.

Lehninger, B.L. (1975) Biochemistry. Worth Publishers Inc., New York.

Lin, T., Murono, E., Osterman, J., Nankin, H. \& Coulson, P.B. (1981) Gossypol inhibits testicular steroidogenesis. Fert. Steril. 35, 563-566.

Lowry, O.H., Rosebrough, H.N., Farr, A.L. \& Randall, R.H. (1951) Protein measurement with the folin phenol reagent. J. biol. Chem. 193, 265-275.

Martinek, R.G., Berger, L. \& Broids, D. (1964). Simplified estimation of leucine aminopeptidase activity. Clin. chem. 10, 1087-1091.

Mohan, J., Panda, J.N. \& Singh, U.S. (1987) Serotonin and indomethacin administration in chicken affect semen angiotensin converting enzyme and phosphomonoesterases. Med. Sci. Res. 15, 1239-1240.

National Coordinating Group on Male Infertility Agents (1978) Gossypol, a new antifertility agent for males. Chinese med. J. 4, 417-428.

Pelletier, R.M. \& Friend, D.S. (1980) Effect of the experimental contraceptive agent gossypol on guinea pig,
Sertoli-Sertoli cell junctions. J. Cell Biol. 87, 151a, Abstr.

Prasad, M.R.N. \& Diczfalusy, E. (1982) Gossypol. Int. J. Androl. (Suppl.) 5, 53-69.

Rojas, S.W. \& Scott, M.L. (1969) Factors affecting the nutritive value of cotton seed meal as a protein source in chick diets. Poult. Sci. 48, 819-835.

Saeki, Y. \& Morichi, T. (1959) The male in reproduction. In Physiology and Biochemistry of the Domestic Fowl, vol. III, p. 1425. Eds D. J. Bell \& B. M. Freeman. Academic Press, New York.

Sexton, T.J. (1977) A new poultry semen extender. 1. Effect of extension on the fertility of chicken semen. Poult. Sci. 56, 1443-1446.

Sharlin, J.S., Howarth, B., Jr, Thompson, F.N. \& Wyatt, R.D. (1981) Decreased reproductive potential and reduced feed consumption in mature White Leghorn males fed aflatoxin. Poult. Sci. 60, 2701-2708.

Shi, O.X. \& Friend, D.S. (1983) Effect of gossypol acetate on guinea-pig sperm maturation and capacitation. Biol. Reprod. 28 (Suppl.), 158, Abstr.

Singh, U.S., Kumar, M.V. \& Panda, J.N. (1985) Angiotensin converting enzyme in semen and its possible role in capacitation. Andrologia 17, 472-475.

Stambaugh, R. \& Buckley, J. (1970) Comparative studies of the acrosomal enzymes of rabbit, rhesus monkey, and human spermatozoa. Biol. Reprod. 3, 275-282.

Stambaugh, R., Brackett, B.G. \& Mastroianni, L. (1969) Inhibition of in vitro fertilization of rabbit ova by trypsin inhibitor. Biol. Reprod. 1, $223-227$.

Tanksley, T.D., Jr, Neumann, H., Lyman, C.M., Pace, C.N. \& Prescott, J.M., (1970) Inhibition of pepsinogen activation by gossypol. J. biol. Chem. 245, 6456-6461.

Tso, W.W. \& Lee, C.S. (1982) Gossypol: an effective acrosin blocker. Archs Androl. 8, 143-147.

Wilson, E.K., Rogler, J.C. \& Erb, R.E. (1979) Effect of sexual experience, location, malnutrition and repeated sampling on concentrations of testosterone in blood plasma of Gallus domesticus roosters. Poult. Sci. 58, 178-186.

Xue, S.P., Jong, S.D., Su, S.Y., Wu, Y.W., Liu, Y., Zhou, Z.G. \& Ma, X.X. (1980) Antifertility effect of gossypol on the germinal epithelium of the rat testis. A cytological, autoradiographical, and ultrastructural observation. Sci. Sin. 23, 642-657.

Received 22 March 1988 